\title{
Comparison of behavioral patterns of South American sea lions between breeding and non-breeding seasons
}

\author{
Comparación de los patrones conductuales del lobo marino común \\ en época reproductiva y no reproductiva
}

\author{
M. José Pérez-Alvarez ${ }^{1,2,3}$, Pablo Carrasco4, Maritza Sepúlveda ${ }^{2,3}$ \\ and Renato A. Quiñones ${ }^{4}$
}

\begin{abstract}
${ }^{1}$ Instituto de Ecología y Biodiversidad (IEB), Facultad de Ciencias, Universidad de Chile, Las Palmeras 3425, Ñuñoa, Santiago, Chile.mjose.perez@eutropia.cl

${ }^{2}$ Centro de Investigación Eutropia, Ahumada 131 Oficina 912, Santiago, Chile

${ }^{3}$ Centro de Investigación y Gestión en Recursos Naturales (CIGREN), Facultad de Ciencias, Universidad de Valparaíso, Av. Gran Bretaña 1111, Playa Ancha, Valparaíso, Chile

${ }^{4}$ Programa de Investigación Marina de Excelencia (PIMEX), Facultad de Ciencias Naturales y Oceanográficas, Universidad de Concepción, Casilla 160-C, Concepción, Chile
\end{abstract}

\begin{abstract}
Resumen.- Se han descrito tácticas reproductivas para machos y hembras en sistemas reproductivos poligínicos, dentro de las cuales, una respuesta conductual sexo-específico sería esperable para maximizar el éxito reproductivo. El presente estudio da cuenta de un seguimiento conductual del lobo marino común Otaria flavescens durante la época reproductiva (ER) y no reproductiva (ENR) en el Santuario de la Naturaleza Lobería Cobquecura, Chile central. Se registraron patrones conductuales de machos, hembras, juveniles y crías entre mayo de 2008 y diciembre de 2009. Los machos presentaron más registros de conductas asociadas a agresión, desplazamiento y reconocimiento durante ER, mientras que la conducta descanso fue mayor durante ENR. Hembras y juveniles presentaron mayores registros de reconocimiento durante ENR mientras que las otras categorías conductuales no presentaron diferencias entre ER y ENR. Las conductas agresivas por parte de los machos así como las relacionadas al cuidado parental por parte de las hembras podrían ser estrategias conductuales desarrolladas por ambos sexos para asegurar la viabilidad poblacional. Este estudio contribuye al conocimiento de los patrones conductuales reproductivos de la especie y forma parte de uno de los seguimientos conductuales reproductivos más continuos desarrollados en la actualidad en el lobo marino común. Dado que el estudio se realiza en un área protegida dentro del marco legal de Santuario de la Naturaleza, los resultados expuestos serán de utilidad para futuras comparaciones con loberas reproductivas afectadas por actividad antrópica.
\end{abstract}

Palabras clave: Sistema reproductivo poligínico, comportamiento reproductivo, otáridos, Otaria flavescens, Chile

\begin{abstract}
In a polygynous mating system males and females have different reproductive strategies; so it is expectable that both sexes have evolved different reproductive behavioral responses to maximize their reproductive success. We analyze the behavior of different sex/age classes of Otaria flavescens during breeding (BS) and non-breeding seasons (NBS) at a Nature Sanctuary breeding colony, central Chilean coast. From May 2008 to December 2009 data of males, females, juveniles and pups were recorded. Males performed more aggression, locomotion and recognizing behaviors during the BS, while they mostly rested during the NBS. Females and juveniles performed more recognizing behavior in the NBS, while the other behavior categories did not show differences between the NBS and the BS. As reproductive behavioral strategies, male aggression and maternal care may increase the overall population viability. This study contributed to a better understanding of the reproductive behavior patterns of this species based on what is to our knowledge the most continuous monitoring of a South American sea lion breeding colony. Since the study has been undertaken in a Nature Sanctuary, the results may be used as a baseline to compare with behavioral data from colonies perturbed by human activities.
\end{abstract}

Key words: Polygynous mating system, reproductive behavior, otariids, Otaria flavescens, Chile

\section{INTRODUCTION}

In a polygynous mating system, males and females maximize their reproductive success in different ways. In general, males tend to maximize reproductive success by mating with as many females as possible to increase the number of offspring. In contrast, females can produce only a limited number of young and must maximize their reproductive success by producing and successfully rearing high quality offspring (Cézilly \& Danchin 2008). 
In most otariid species (sea lions and fur seals), as in other mammals, the predictable spatial and temporal clustering of breeding females has favored the evolution of a polygynous mating system (Coltman et al. 1998). In otariids, maternal gestation and lactation provide the nutrient requirements for developing young and consequently females provide most of the parental care (Boness \& Bowen 1996). Thus males are free to devote the bulk of their time and energy to competing for access to receptive females (Mesnick \& Ralls 2002, Tyack 2002). Hence, since males and females have different reproductive goals, it is expectable that the sexes have evolved different behavioral adaptations to maximize their reproductive success (Tyack 2002).

During the breeding season, males perform territoriality displays and defense tactics to attempt to monopolize females directly (Boness et al. 2006). In this period fighting among males is frequent, especially during the first few days of the breeding season when territorial boundaries are being established (Riedman 1990). Once boundaries are established, fighting and agonistic displays between neighboring males become less frequent, although they may advertise their ownerships by constant vocalizing and aggressive displays (Cassini 2003). Males of several species of otariids are also able to herd females, preventing them from leaving their territories (Campagna \& LeBoeuf 1988a). Females, in contrast, perform different agonistic behaviors during this period mainly related to the care of their pups. First, females choose the territory to haul-out and when the pup is born, it has to display recognition behaviors. Mutual vocal and olfactory recognition are common in otariids, due to the fact that mothers and pups often separate during the mother's foraging trips and the reunion depends on mutual recognition (Mann 2002, Trimble \& Insley 2010, Trimble \& Charrier 2011).

During the non-breeding season, otariid males do not need to defend a female and/or a territory; females distribute their time between taking care of their offspring on land and foraging in the ocean (Bonner 1984, Campagna \& Le Boeuf 1988a). Thus it is expected that the dissimilarities between breeding and non-breeding seasons will be reflected in different behavioral patterns displayed by males and females, and in general in the activity budget of otariids. Unfortunately, the partitioning of behavioral activities for different otariids outside the breeding season has received much less attention. A study done by Johnstone \& Davis (1987) found that the activity budget of males of the New Zealand fur seal
(Arctocephalus forsteri) during the non-breeding season differs markedly from the activities performed during the breeding season.

The South American sea lion Otaria flavescens (Shaw, 1800) represents an interesting study species with a polygynous social mating system (Campagna 1985, Fernandez-Juricic et al. 2003, Cassini 2003). The breeding period extends from about the third week of December to March (austral summer) (Aguayo \& Maturana 1973, VazFerreira 1982, Acevedo et al. 2003). During this period males defend territories (breeding sites) and/or females (Campagna \& Le Boeuf 1988a, b, Cappozzo 2002). Females copulate and give birth within the territories established by the males (Campagna \& LeBoeuf 1988a, Sielfeld 1999, Acevedo et al. 2003). At the end of the breeding season, reproductive activity ceases and the abundance of males gradually decrease (Sepúlveda et al. 2001, Acevedo et al. 2003). Since pups are not able to swim long distances, females remain with their pups in the colony until May, and leave the breeding colony once pups are more proficient swimmers (Sepúlveda et al. 2009).

Behavioral studies of $O$. flavescens have been mostly undertaken along the Atlantic coast of South America (Argentina) (Fernandez-Juricic et al. 2003, Cassini \& Fernandez-Juricic 2003, Fernandez-Juricic \& Cassini 2007, Cappozzo et al. 2008), and have been mainly focused on a specific age class category. In Chile there have been few studies on the reproductive behavior of this species (Rivera 1990, Acevedo 2000). All of the mentioned studies were performed in a short time period and only during the breeding season, so fluctuations in behavior, whether seasonally or per age and sex classes were not the focus of the past studies. Here we report detailed observations of South American sea lion behavior during almost 2 years in a breeding colony of the central coast of Chile. In order to investigate whether the breeding period has an effect on the behavior of the species, behavioral activities of different age and sex classes of $O$. flavescens were analyzed, covering both the breeding and non-breeding seasons.

\section{MATERIALS AND METHODS}

\section{STUDY AREA}

The study was conducted at the Cobquecura breeding colony, Lobera Cobquecura, situated in the central coast of Chile ( $36^{\circ} 07^{\prime}$ S; $72^{\circ} 48^{\prime} \mathrm{W}$ ) (Fig. 1). The Cobquecura colony is a chain of three rock formations, distant 


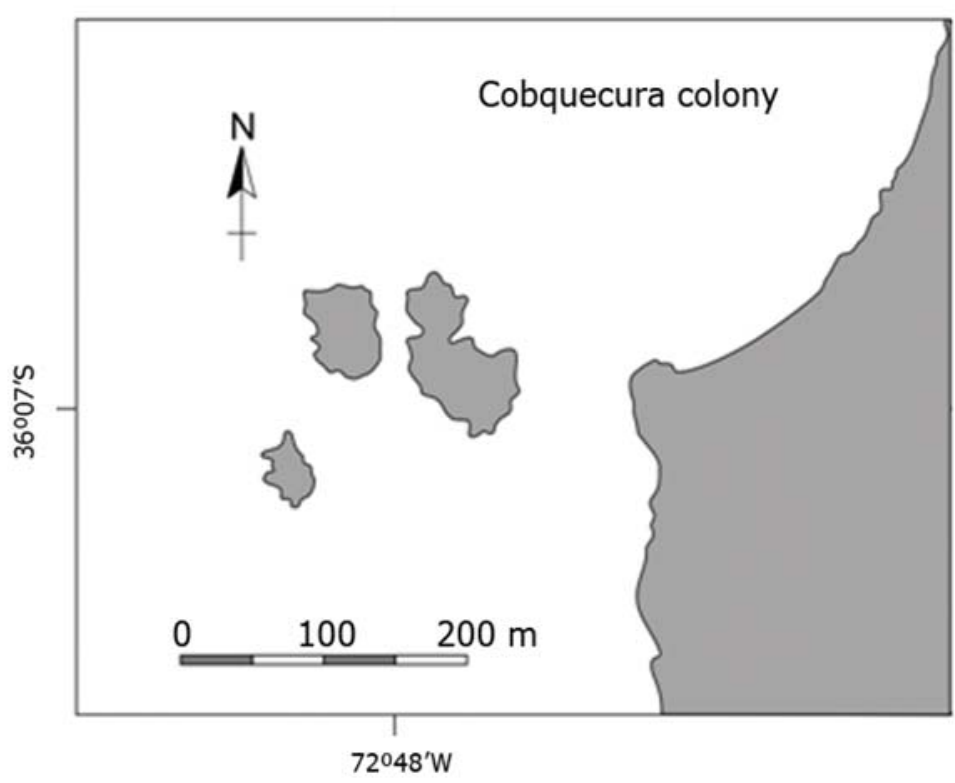

Figure 1. Geographic location of the South American sea lion (Otaria flavescens) breeding colony, Lobera Cobquecura, central coast of Chile / Ubicación geográfica de la lobera reproductiva del lobo marino común (Otaria flavescens), Lobera Cobquecura, Chile central

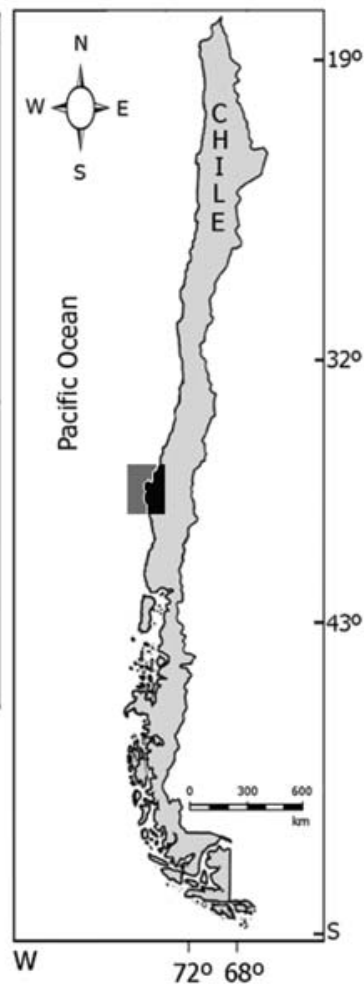

approximately $80-100 \mathrm{~m}$ from the coast. Cobquecura is the most important sea lion colony of the central Chilean coast, with nearly 2,500 individuals (Sepúlveda et al. 2011). The Cobquecura colony is part of an area officially declared as a Nature Sanctuary by the Chilean Government in 1992 (Quiñones et al. 2011) ${ }^{1}$

\section{ETHOGRAMS DESIGN}

From mid May 2008 to late December 2009 a total of 1,305 individuals were observed. The study period was divided into 'breeding season' (BS) (from December $19^{\text {th }}$ to March $18^{\text {th }}$ ) and 'non-breeding season' (NBS) (from March $19^{\text {th }}$ to December $18^{\text {th }}$ ). These dates were selected according to the reproductive events described by Acevedo et al. (2003). Behavioral patterns were assessed by focal time sampling following Altmann (1974) and Martin \& Bateson (1993). Observations were conducted 2-3 days/week by 2 experimented observers, completing a total of 7-8 sessions per day, from 09:00 to 17:00 hrs. The data was recorded alternately by the observers. Each session lasted $45 \mathrm{~min}$ and behavior was recorded at 5-min sample intervals for a randomly selected individual. Individuals were observed using $10 \times 15$ binoculars and a konuspot65 15-45x65 zoom spotting scope.

\section{BEHAVIOR CATEGORIES}

Five behavior categories and one 'out of sight' category were previously identified in the colony, and their occurrence was recorded during the complete study period (Table 1). Similar behavioral categories have been used in other studies of terrestrial and aquatic mammals (Schusterman 1981, Mallapur et al. 2005, Klinka \& Reimchen 2009, Gerber et al. 2010, Smith \& Litchfield 2010). Individuals were classified into 4 classes according to sex and age: adult males (M), adult females (F), juveniles (J) (both sexes, including yearlings born during the

${ }^{1}$ Quiñones RA, M Sepúlveda, P Carrasco, MJ Pérez, R Moraga, L Hückstädt \& E Pedreros. 2011. Ecología y biología del lobo marino común, Otaria flavescens, en el Santuario Islote Lobería de Cobquecura. Informe de Avance Período Mayo 2008-Diciembre 2010. Programa de Investigación Marina de Excelencia (PIMEX), Facultad de Ciencias Naturales y Oceanográficas, Universidad de Concepción, Concepción, 148 pp. 
Table 1. Description of the behavioral categories recorded in the study of the South American sea lion (Otaria flavescens) in Cobquecura breeding colony, central Chile / Descripción de las categorías conductuales registradas en el estudio del lobo marino común (Otaria flavescens) en la Lobera Cobquecura, Chile central

\begin{tabular}{|c|c|}
\hline Behavior & Description \\
\hline Recognition & $\begin{array}{l}\text { Individual examines other animals. Includes vocalizations mother-pups, smelling } \\
\text { and staring behaviors. }\end{array}$ \\
\hline Rest & $\begin{array}{l}\text { Individual maintains a stationary position, including lying, stretching or } \\
\text { scratching. }\end{array}$ \\
\hline Locomotion & Individual moves from one site to another. \\
\hline Aggression or confrontation & Individual reared up its body, vocalizing, chasing and biting other animals. \\
\hline Retreat and inferiority & Individual moves away from the opponent animal. \\
\hline Out of sight & $\begin{array}{l}\text { Focal animal has moved out of sight and it is not possible to see what the individual } \\
\text { is doing }\end{array}$ \\
\hline
\end{tabular}

previous season), and pups (P). Age and sex were determined from differences in size, body shape and/or coloration (Hamilton 1934, King 1983). The pup category (born during the current breeding season) was considered between January to mid March (BS) due their diagnostic characteristics and easy identification. After their first molt, they are easily confused with the juvenile category, so during NBS pups were included in the juvenile category in order to minimize misclassification.

\section{Data ANALYSES}

To test whether the behavioral categories varied between the BS and the NBS for each sex/age class, and if the behavioral categories differ among them within each season 2x2 contingency tables were carried out (Zar 1999). During the NBS the pup category was not considered, as mentioned above. All the analyses were performed in Statistica 7.0 (StatSoft, Inc. 2004) and the significance level was set at $\alpha=0.05$.

\section{RESUlts}

All the behavioral categories established were observed for the South American sea lion during the study period. Overall, the most common activity for $O$. flavescens was resting (R), both in the BS and NBS (Fig. 2). Also, in both periods recognition was the second most frequent category observed followed by locomotion, aggression and retreat (Fig. 2).

Behavior categories were analyzed for each sex/age class during the BS and the NBS (Fig. 3). The most common sex/age category recorded was males (40.68\%), then females (30.13\%), juveniles (24.11\%) and finally pups (5.05\%). During the BS, resting behavior was more commonly observed in males and females in comparison to juveniles (M-J: $\chi^{2}=18.07$, d.f $=1, P<0.0001$; F-J: $\chi^{2}=28.89$, d.f $\left.=1, P<0.0001\right)$ and pups (M-P: $\chi^{2}=58.68$, d.f $=1, P<0.0001$; F-P: $\chi^{2}=75$, d.f $=1, P<0.0001$ ). Recognition was more frequently recorded for pups than males (P-M: $\chi^{2}=9.5$, d.f. $=1, P<0.01$ ) and females (P-F: $\chi^{2}=11.92$, d.f. $\left.=1, P<0.001\right)$. Males performed more aggressive activities than females (M-F: $\chi^{2}=3.7$, d.f. $=1$, $P<0.05$ ) and pups, but not more than juveniles (M-P: $\chi^{2}=$ 3.7, d.f. $=1, P<0.05 ; \mathrm{M}-\mathrm{J}: \chi^{2}=1.05$, d.f. $=1, P=0.306$ ). No significant differences were obtained for locomotion and retreat behaviors among the different age and sex classes (excluding pups).

Similar to the BS, during the NBS resting behavior was more frequently observed in males and females compared to juveniles (M-J: $\chi^{2}=34.03, \mathrm{~F}-\mathrm{J}: \chi^{2}=20.49$, d.f. $=1$, $P<0.0001$ ) (Fig. 3). On the contrary, juveniles showed more recognition behavior than males (J-M: $\chi^{2}=10.35$, d.f. $=1, P<0.01)$. Locomotion activity was significantly less in males than in juveniles (M-J: $\chi^{2}=6.44$, d.f. $=1, P<$ 0.05: M-F: $\chi^{2}=2.45$, d.f. $=1, P=0.11$ ). No significant differences were found by sex/age class for aggression and retreat behaviors.

When behavioral categories were compared between the BS and the NBS, differences according to sex/age classes were identified. For males, resting behavior increased significantly during the NBS $\left(\chi^{2}=86.33\right.$, d.f. $=$ $1, P<0.0001)$. However, they performed more locomotion, recognizing, and aggression during the BS (Locomotion: 
Figure 2. Behavior categories recorded for the South American sea lion (Otaria flavescens), during the (A) Breeding and (B) Non-breeding season, in Cobquecura breeding colony, central Chile. Different letters indicate statistically significant differences between behavioral categories $(\alpha=0.05) /$ Categorías conductuales registradas para el lobo marino común (Otaria flavescens), durante la época (A) Reproductiva y (B) No reproductiva en Lobera Cobquecura, Chile central. Letras diferentes indican diferencias estadísticas significativas $(\alpha=0,05)$ entre categorías conductuales

A

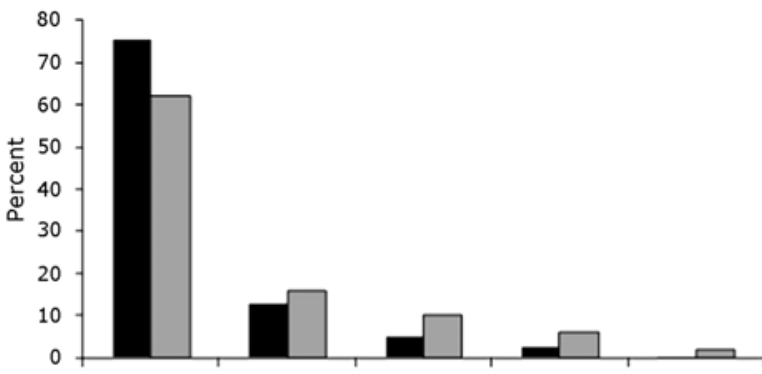

C

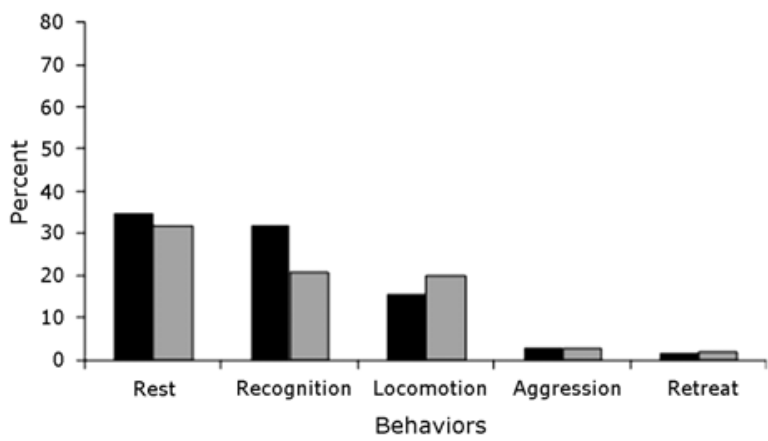

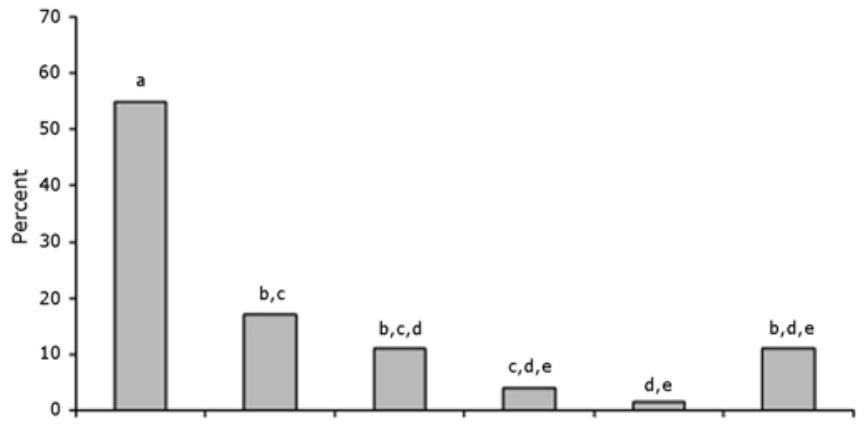

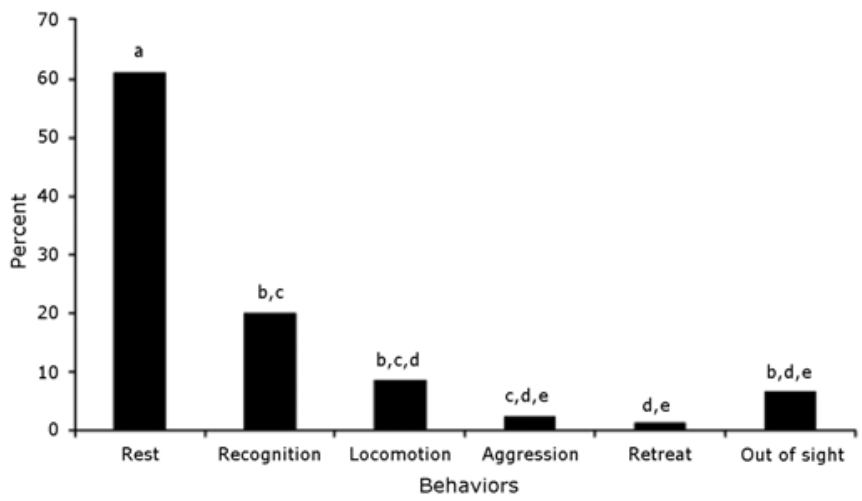

B

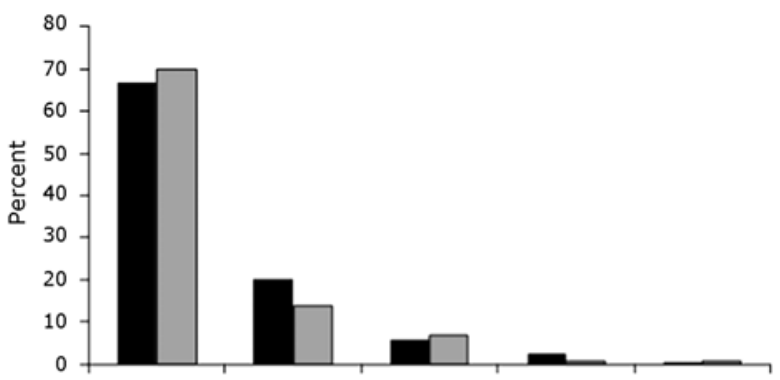

D

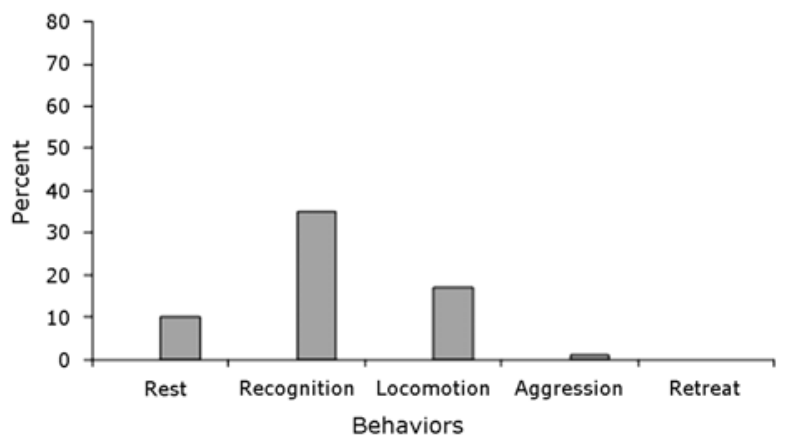

Figure 3. Behavior categories recorded for the South American sea lion (Otaria flavescens) by age and sex classes (A: Males, B: Females, C: Juveniles, D: Pups) during the breeding (gray columns) and non-breeding (black columns) seasons, in Cobquecura breeding colony, central Chile / Categorías conductuales registradas para el lobo marino común (Otaria flavescens) según sexo y categoría etaria (A: Machos, B: Hembras, C: Juveniles, D: Crías) durante la época reproductiva (gris) y No reproductiva (negro) en Lobera Cobquecura, Chile central 
$\chi^{2}=32.95$, d.f. $=1, P<0.00001$; Recognizing: $\chi^{2}=5.40$, d.f. $=1, P<0.05$; Aggression: $\chi^{2}=31.1$, d.f. $=1, P<0.0001$ ). Females and juveniles showed a higher frequency of recognizing behavior in the NBS $\left(\chi^{2}=20.04\right.$, d.f. $=1, P<$ $0.0001 ; \chi^{2}=26.6$, d.f. $=1, P<0.0001$, respectively). The other behavior categories did not present significant differences between the NBS and the BS.

\section{Discussion}

This study is a contribution to the understanding of the reproductive behavior of polygynous species of otariids specifically in $O$. flavescens. Our results are based on, to our knowledge, the most continuous monitoring of a South American sea lion breeding colony, and suggest a significant effect of the breeding season on the behavior of this species expressed by changes in behavioral patterns of each sex/age class.

Overall, the most common activity for $O$. flavescens was resting in both breeding and non-breeding seasons. Similar results were found in female Steller sea lions (Eumetopias jubatus) by Milette (1999). This author reports that resting behavior is the main component of the land activity of females, suggesting that they must spend a substantial amount of time resting ashore due to the energetic costs of lactation. Likewise, Boness (1984) mentioned that the high level of inactivity recorded during the BS in male Grey seals (Halichoerus grypus) is due to the fact that males fast and do not devote energy to searching for food. Fasting during the BS should have led to the evolution of a restricted energy regime (Sandregen 1976). Bester \& Rossouw (1994) suggested that inactivity in otariids serves a dual purpose; it is required to supplement physiological thermoregulation, being a behavioral response to restrict endogenous heat loading, and it is probably the most efficient way to reduce energy expenditure.

Recognition activity was, after resting, the most frequent behavioral category observed in this colony all year round and in all sex/age classes. Recognition behavior seems to be an adaptation to gregarious living, and is probably a response to the selection pressures imposed (Picher et al. 2010). This behavior is a critical process for the social structure of the colony and its population dynamics since mother-pup recognition is a critical factor in offspring survival (Fernández-Juricic et al. 1999, Trimble \& Insley 2010, Trimble \& Charrier 2011). Additionally, it is also crucial for identification of the female estrus period (Riedman 1990) and for territorial defense (Campagna \&
Le Boeuf 1988a, Campagna et al. 1988, 1992, FernándezJuricic et al. 2001, 2003), in which males exhibit a complex repertoire of threat calls that are associated with formalized visual display behavior and tend to be individualistic (Insley et al. 2003).

Differences in behavior categories were found for each age and sex class during the BS and the NBS. The results show that for males, resting behavior increased during the NBS, while locomotion, aggression and recognizing behavior rose in the BS. Additionally, males performed more aggressive activities than females and pups. These results are in accordance with the expected for a resourcedefense polygynous breeding system. During the BS, reproductively active males defend territories. Aggressive encounters between males are frequent and males who initiate interactions are usually the ones who hold territories (Gerber et al. 2010). Males chase and bite other individuals as a strategy to monopolize females (Campagna 2002), raising the number of offspring via defense of mates (Campagna 1985, Fernández-Juricic \& Cassini 2007). Harassment of females by males may also contribute to the increment of aggressive behavior during the BS. Males, including satellite males, try to obtain mates by retaining females arriving to the colony from the sea, and initiating group raids into the breeding area to seize females (Campagna et al. 1988). Aggressive behavior begins to decline at the end of the BS mainly due at the end of the breeding season, reproductive activity ceases (Sepúlveda et al. 2001, Acevedo et al. 2003). These may explain the increment of resting behavior performed by males in this study during the NBS. Gerber et al. (2010) mentioned that both male and female behavior influence population viability in the sea lions. Male aggression may separate mother-pup pairs, affecting nursing (Ono \& Boness 1996) or may cause direct mortality of pups due to an increasing in the risk of trampling (Gerber et al. 2010). On contrary, female aggression has been observed as a protection behavior of their pups (Le Boeuf \& Campagna 1994, Campagna 2002), giving protection directly or by securing higher quality resting and breeding areas (Gerber et al. 2010).

Recognizing behavior was more frequently recorded by females and juveniles in the NBS. These results may be associated with the mutual mother-pup recognition demonstrated in otariids (Insley et al. 2003) and with the reproductive behavioral pattern of this species (Campagna 1985, Campagna \& Le Boeuf 1988a, Fernández-Juricic \& Cassini 2007). Females alternate foraging trips at sea with suckling periods ashore, and 
when they return, mother and offspring have to find each other among the individuals in the colony (Charrier et al. 2009, Muñoz et al. 2011). Because in O. flavescens the lactation period is about 8-10 months (Cappozzo \& Perrin 2009), during the NBS most of the juveniles, which correspond to pups that were born during the previous $\mathrm{BS}$, are still nursing. So it is expected a greater recognizing behavior for juveniles and females in the NBS period. On the contrary, during the BS months, the category of juveniles corresponds to individuals of approximately one year of age that were almost or fully weaned.

Our data are consistent with a behavioral reproductive strategy in a polygynous mating system. Since female and male behavior influence female fecundity and consequently population viability, the understanding of behavioral and ecological factors that influence population dynamics may support proactive management plans and better predictions of wildlife responses (Gerber et al. 2010). This study contributed to a better understanding of the reproductive behavior patterns of O. flavescens in central Chile and it supports the importance of long-term behavioral studies in species with different reproductive strategies. Since Cobquecura colony is part of a Nature Sanctuary, our results may be used as a baseline to compare with behavioral data from colonies perturbed by human activities.

\section{ACKNOWLEDgMenTS}

This research is part of the Programa de Investigación Marina de Excelencia (PIMEX-Nueva Aldea) of the Faculty of Natural and Oceanographic Sciences of the Universidad de Concepción, funded by Celulosa Arauco and Constitución S.A. The authors acknowledge Danilo Alegría, Omar Muñoz and Eduardo Pedreros for their help in the field and Andrea Caiozzi for her valuable suggestions regarding ethogram design.

\section{LITERATURE CITED}

Acevedo R. 2000. Repertorio conductual y vocal del lobo marino común Otaria flavescens (Shaw 1800), Montemar, V Región, Chile. Tesis de Biólogo Marino, Universidad de Valparaíso, Valparaíso, 111 pp.

Acevedo J, A Aguayo-Lobo A \& W Sielfeld. 2003. Eventos reproductivos del león marino común, Otaria flavescens (Shaw, 1800), en el norte de Chile (Pacífico Suroriental). Revista de Biología Marina y Oceanografía 38: 69-75.

Aguayo A \& R Maturana. 1973. Presencia del lobo marino común (Otaria flavescens) en el litoral chileno. Arica a Punta Maiquillahue. Biología Pesquera 6: 45-75.
Altmann J. 1974. Observational study of behaviour: Sampling methods. Behaviour 49: 227-267.

Bester M \& G Rossouw. 1994. Time budgets and activity patterns of sub-Antartic fur seals at Gough Island. South African Journal of Zoology 29: 168-174.

Boness D. 1984. Activity budget of male gray seals, Halichoerus grypus. Journal of Mammalogy 65: 291-297.

Boness D \& W Bowen. 1996. The evolution of maternal care in pinnipeds. Bioscience 46: 645-654.

Boness D, W Bowen, B Buhleier \& G Marshall. 2006. Mating tactics and mating system of an aquatic-mating pinniped: the harbor seal, Phoca vitulina. Behavioral Ecology Sociobiology 61: 119-130.

Bonner W. 1984. Lactation strategies in pinnipeds: problems for a marine mammalian group. In: Peaker M, RG Vernon \& $\mathrm{CH}$ Knight (eds). Physiological strategies in lactation. Symposia of the Zoological Society of London 51: 253372. Academic Press, London.

Campagna C. 1985. The breeding cycle of the southern sea lion, Otaria byronia. Marine Mammal Science 1: 210-218.

Campagna C. 2002. Aggressive behavior (intraspecific). In: Perrin W, B Würsig \& J Thewissen (eds). Encyclopedia of marine mammals, pp. 13-16. Academic, San Diego.

Campagna C \& B Le Boeuf. 1988a. Reproductive behaviour of southern sea lions. Behaviour 104: 233-261.

Campagna C \& B Le Boeuf. 1988b. Thermoregulatory behavior in the sea lion and its effect on the mating system. Behaviour 107: 72-90.

Campagna C, B Le Boeuf \& H Cappozzo. 1988. Groups raids: a mating strategy of male southern sea lions. Behaviour 105: 224-249.

Campagna C, C Bisioli, F Quintana, F Perez \& A Vila. 1992. Group breeding in sea lions: pups survive better in colonies. Animal Behavior 43: 541-548.

Cappozzo H. 2002. South American sea lions Otaria flavescens. In: Perrin W, B Würsig \& J Thewissen (eds). Encyclopedia of marine mammals, pp. 1143-1146. Academic Press, San Diego.

Cappozzo H, J Túnez \& M Cassini. 2008. Sexual harassment and female gregariousness in the South American sea lion, Otaria flavescens. Naturwissenschaften 95(7): 625-630.

Cappozzo H \& W Perrin. 2009. South American sea lion Otaria flavescens. In: Perrin W, B Würsig \& J Thewissen (eds). Encyclopedia of marine mammals, pp. 1076-1079. Academic Press/Elsevier, Amsterdam.

Cassini M. 2003. The evolution of reproductive systems in pinnipeds. Behavioral Ecology 10(5): 612-616.

Cassini M \& E Fernández-Juricic. 2003. Costs and benefits of joining South American sea lion breeding units: testing the assumptions of a model on female breeding dispersion. Canadian Journal of Zoology 81: 1154-1160. 
Cézilly F \& E Danchin. 2008. Mating system and parental care. In: Danchin E, LA Giraldeau \& F Cezilly (eds). Behavioural ecology, pp. 429-465. Oxford University Press, Oxford.

Charrier I, B Pitcher \& R Harcourt. 2009. Vocal recognition of mothers by Australian sea lion pups: individual signature and environmental constraints. Animal Behavior 78: 11271134.

Coltman D, W Bowen \& J Wright. 1998. Male mating success in an aquatically mating pinniped, the harbor seal (Phoca vitulina) assessed by microsatellite DNA markers. Molecular Ecology 7: 627-638.

Fernández-Juricic E \& M Cassini. 2007. Intra-sexual female agonistic behaviour of the South American sea lion (Otaria flavescens) in two colonies with different breeding substrates. Acta Ethologica 10: 23-28.

Fernández-Juricic E, E Campagna, C Enriquez \& C Ortiz. 1999. Vocal communication and individual recognition in breeding South American sea lions. Behaviour 136: 495517.

Fernández-Juricic E, E Campagna, C Enriquez \& C Ortiz. 2001. Vocal rates and social context in male South American sea lions. Marine Mammal Science 17: 387-396.

Fernández-Juricic E, C Campagna \& D San Mauro. 2003. Variations in the arrangement of South American sea lion (Otaria flavescens) male vocalizations during the breeding season: patterns and contexts. Aquatic Mammals 29(2): 289-296.

Gerber L, M González-Suárez, C Hernández-Camacho, J Young \& J Sabo. 2010. The cost of male aggression and polygyny in California sea lions (Zalophus californianus). PloS ONE 5: 1-8.

Hamilton J. 1934. The southern sea lion Otaria byronia (de Blainville). Discovery Reports 8: 269-318.

Insley S, A Phillips \& I Charrier. 2003. A review of social recognition in pinnipeds. Aquatic Mammals 29(2): 181201.

Johnstone R \& L Davis. 1987. Activity in a non-breeding colony of New Zealand fur seals, Arctocephalus forsteri. New Zealand Journal of Marine and Freshwater Research 21: 153-155.

King J. 1983. Seals of the world, 240 pp. Cambridge University Press, Cambridge.

Klinka D \& T Reimchen. 2009. Darkness, twilight, and daylight foraging success of bears (Ursus americanus) on salmon in coastal British Columbia. Journal of Mammalogy 90: 144-149.

Le Boeuf B \& C Campagna. 1994. Protection and abuse of young in pinnipeds. In: Parmigiani S \& FS Vom Saal (eds). Infanticide and parental care, pp. 257-276. Harwood Academic Publishers, Chur.
Mallapur A, N Waran \& A Sinha. 2005. Factors influencing the behaviour and welfare of captive lion-tailed macaques in Indian zoos. Applied Animal Behavior Science 91: 337353.

Mann J. 2002. Parental behavior. In: Perrin WF, B Würsig \& JGM Thewissen (eds). Encyclopedia of marine mammals, pp. 876-882. Academic Press, San Diego.

Martin P \& P Bateson. 1993. Measuring behavior. Introductory guide, 200 pp. Cambridge University Press, Cambridge.

Mesnick S \& K Ralls. 2002. Mating systems. In: Perrin WF, B Würsig \& JGM Thewissen (eds). Encyclopedia of marine mammals, pp. 726-733. Academic Press, San Diego.

Milette L. 1999. Behaviour of lactating Steller sea lions (Eumetopias jubatus) during the breeding season: A comparison between a declining and stable population in Alaska. MSc Thesis, University of British Columbia, Vancouver. <http://www.marinemammal.org/pdfs/ Milette99.pdf $>$

Muñoz L, G Pavez, P Inostroza \& M Sepúlveda. 2011. Foraging trips of females South American sea lions (Otaria flavescens) in Isla Chañaral, Chile. Latin American Journal Aquatic Mammals [Accepted][In Press]

Ono K \& D Boness. 1996. Sexual dimorphism in sea lion pups: differential maternal investment, or sex-specific differences in energy allocation? Behavioral Ecology and Sociobiology 38: 31-41.

Pitcher B, R Harcourt \& I Charrier. 2010. Rapid onset of maternal vocal recognition in a colonially breeding mammal, the Australian sea lion. Plos One 5(8): 1-7.

Riedman M. 1990. The pinnipeds; seals, sea lions and walruses, 439 pp. University of California Press, Berkeley.

Rivera A. 1990. Etología: displays agonísticos presentes en Otaria flavescens (Shaw 1800), Punta Hualpén, Chile. Gayana 54: 33-49.

Sandregen F. 1976. Agonistic behavior in the male Northern elephant seal. Behaviour 57: 137-157.

Schusterman R. 1981. Steller sea lion Eumetopias jubatus. In Ridgway S \& R Harrison (eds). Handbook of marine mammals 1: 119-141. Academic Press, New York.

Sepúlveda M, D Oliva \& F Palma. 2001. Daily and annual circarhythms activity in the South American sea lion Otaria flavescens (Carnivora: Otariidae) at the central zone of Chile. Revista de Biología Marina y Oceanografía 36: 181-187.

Sepúlveda M, P Inostroza, MJ Pérez-Alvarez, D Oliva \& R Moraga. 2009. Seasonal variation in the abundance of South American sea lions Otaria flavescens (Shaw, 1800) in Chañaral Island, Reserva Nacional Pingüino de Humboldt, Chile. Revista de Biología Marina y Oceanografía 44(3): 685-689. 
Sepúlveda M, D Oliva, A Urra, MJ Pérez, R Moraga, D Schrader, P Inostroza, A Melo, H Díaz \& W Sielfeld. 2011. Distribution and abundance of the South American sea lion Otaria flavescens (Carnivora: Otariidae) along the central coast off Chile. Revista Chilena de Historia Natural 84: 97-106.

Sielfeld W. 1999. Estado del conocimiento sobre conservación y preservación de Otaria flavescens (Shaw 1800) y Arctocephalus australis (Zimmermann 1783) en las costas de Chile. Estudios Oceanológicos 18: 81-96.

Smith B \& C Litchfield. 2010. An empirical case examining effectiveness of environmental enrichment in two captive Australian sea lions (Neophoca cinerea). Journal of Applied Animal Welfare Science 13: 103-122.

Trimble M \& S Insley. 2010. Mother-offspring reunion in the South American sea lion Otaria flavescens at Isla de Lobos (Uruguay): use of spatial, acoustic and olfactory cues. Ethology Ecology \& Evolution 22: 233-246.
Trimble M \& I Charrier. 2011. Individuality in South American sea lion (Otaria flavescens) mother-pup vocalizations: Implications of ecological constraints and geographical variations? Mammalian Biology 76: 208-216.

Tyack P. 2002. Behavior, overview. In: Perrin WF, B Würsig \& JGM Thewissen (eds). Encyclopedia of marine mammals, pp. 87-94. Academic, San Diego.

Vaz-Ferreira R. 1982. Otaria flavescens (Shaw) South American sea lion. Report of the Advisory Committee on marine resources research working party on marine mammals. FAO Fisheries Series 5: 477-495.

Zar J. 1999. Biostatistical analysis, 860 pp. Prentice-Hall International, Upper Saddle River.

Received 26 September 2012 and accepted 6 March 2013

Associated Editor: Mauricio Landaeta D. 